\title{
Governance and Globalization
}

\author{
Bislev, Sven; Salskov-Iversen, Dorte; Krause Hansen, Hans
}

Document Version

Final published version

Publication date:

2001

License

CC BY-NC-ND

Citation for published version (APA):

Bislev, S., Salskov-Iversen, D., \& Krause Hansen, H. (2001). Governance and Globalization. Department of Intercultural Communication and Management, Copenhagen Business School. Working Paper / Intercultural Communication and Management No. 42

Link to publication in CBS Research Portal

\section{General rights}

Copyright and moral rights for the publications made accessible in the public portal are retained by the authors and/or other copyright owners and it is a condition of accessing publications that users recognise and abide by the legal requirements associated with these rights.

Take down policy

If you believe that this document breaches copyright please contact us (research.lib@cbs.dk) providing details, and we will remove access to the work immediately and investigate your claim. 
IKL

Department of Intercultural Communication and Management

Working Paper no. 42, 2001

Governance and Globalization:

Security privatization on the US-Mexican Border. A new role for non-state actors in security provision?

Presented at the Business Association of Latin American Studies Annual Conference April 4-7, University of San Diego

Track: Culture, Social and Ethical Issues (alternatively: Regulatory and Institutional Design)

Sven Bislev, Dorte Salskov-Iversen \& Hans Krause Hansen

(sb.ikl@,cbs.dk.) (dsi.ikl@,cbs.dk) (hkh.ikl@cbs.dk)

Associate professors,

Department of Intercultural Communication and Management

Copenhagen Business School

Dalgas Have 15

DK-2000F

Tel: +4538153815

Fax: +45 38153840 


\title{
Governance and Globalization:
}

\section{Security privatization on the US-Mexican Border. A new role for non-state actors in security provision?}

\begin{abstract}
The domain of security is currently being framed and governed in new ways, involving a broader range of issues and organizational forms. Such organizational forms include non-state actors - e.g. private businesses and NGOs - operating at multiple levels and stretching the concept of security into new policy areas. Drawing on theories of governance and preliminary empirical findings, this paper sketches the security domain and its transformation in the San Diego-Tijuana border region of Southern California.
\end{abstract}

\section{Introduction}

This paper is about the changing character of the security problem in a border region - the San Diego-Tijuana region of Southern California (US) and Baja California (Mexico). The developments in this border region are seen as exemplifying the changing nature of the state in the face of globalization, with the problem of security as an apposite example. For one thing, economic globalization and international integration have changed the nature of sovereignty, and the role of the nation-state in handling security matters has been modified. Other actors have been brought into the picture: regional and local authorities, NGOs and not least businesses are participating, greatly dispersing the handling of many issues, not least the problem of security. Secondly, the meaning of 'security' has changed, and security concerns now address social and economic issues as much as problems of violent conflict. The domain of security - the field where issues of security are defined and acted upon - is, in other words, framed and governed in new ways, involving a broader range of issues and actors and new organizational forms that operate at multiple levels.

The present paper constitutes the preliminary steps in preparation for a study of the security domain and its transformations. As such it serves to map out the orientation of future empirical work on the division of labour between the state and non-state actors, including private business, in the security domain and the effects of this on statecraft. Against this backdrop, we have chosen to focus on a border region for two reasons. In border regions we encounter the classical form of security institutionalization, involving national/federal authorities on both sides of the border: the military and police inspection and regulation of transborder flows of commodities and persons. The security concept articulated in relation to the material and human movement in border regions is conventionally that of 'national security', which in turn is linked to the notion of 'national interests'. Importantly, these concepts incorporate the rationality of sovereignty and its concomitant anticipation of inter-state conflict. Second, in some border regions security institutionalization entails somewhat more than the regulation of transborder flows, adding lower levels of state authority and increasingly also non-state actors to the handling of issues stemming from fierce urbanization: traffic safety, social and environmental matters, conflicts over work and property, and urban crime. The security concept articulated in relation to such matters is conventionally relating to intra-state affairs and conflicts, e.g. 'urban security' or 'human security'.

Evidently, a special feature of the SD-T border region is its high level of cross-border interaction in a context of deep social and economic cross-border inequality. The border also demarcates sharp political and institutional differences, and a high degree of cultural complexity is present on both sides of it. The complexity of this situation notwithstanding, political co-operation between the two cities has been growing since the early 1990s. A multitude of actors and agendas have become involved in the management of security, ranging from state authorities at different levels, over NGOs and public safety councils to private security companies. Such processes make the SD-T border a very interesting case: it demonstrates the simultaneous presence of classical, inter-state security institutionalization and intra-state security institutionalization at the urban levels, 
and it witnesses an emerging local transborder governance agenda which to some extent challenges traditional, federal thinking on both sides of the border. Thus the SD-T border region appears to be an ideal laboratory for studying the transformation of the security domain and the role of state authorities, a condensation of characteristic effects of globalization and regionalization.

Section 1 sketches a regime framework, which has shaped transformations of the security domain, through the lens of 'governance' (Pierre 2000): Conceptually, governance usually refers to the co-ordination of social systems and the role of the state in that process (Pierre 2000:3). The focus will be on the two states' capacities for steering the domain of security in a border region, where an interesting instantiation of dispersed governance can be observed and where current developments challenge and stretch the concept of multi-level governance. Globalization and international integration are changing the nature of sovereignty and diminishing the role of the nation-state in handling security matters. This development reflects deep changes in the way ruling is conceived of and practiced.

Section 2 will briefly examine the security domain in the SD-T region - how it is represented, institutionalized and handled locally by a variety of social and political actors. The section does not pretend to give a systematic overview of the security problems or issues present in the region. Rather, it seeks to capture some of the fora and organizational forms that in different ways construct and operate in the domain of security, with a particular eye to their institutionalization and discourses of security. Produced and disseminated in networks that negotiate societal issues, such discourses can be seen as part of the practices of power and ruling (Salskov-Iversen, Hansen and Bislev 2000; Miller and Rose 1990).

\section{Globalization, the state and transnational integration}

Ever since it began to make sense to think of San Diego and Tijuana as a region, rather than merely two adjacent geographical spaces, this region was set to undergo some form of 'spontaneous' integration: after the US conquest of California, a line was drawn in the sand, and south of it, Mexico continued as Baja California. There was little of economic interest going on south of the line, so, for a long while, the pressure on the newly-established national border was negligible; the border was guarded, but not with any great efficiency.

However, when national regulations and federal subsidies created a prosperous USCalifornian agricultural sector, the border was activated as an institution of critical importance in the attempts at controlling the increasing flows of people and goods. The city of San Diego also grew, Tijuana became established as a leisure spot for US citizens, traffic across the border expanded and the national governments on both sides began to pay more attention to the economic potential of the region. The existence of a national border was not an absolute hindrance to transactions across it, on the contrary. Over time it was increasingly being used to create traffic that might otherwise not have taken place. Cross-border movement expanded from 1942 and onwards as the federal governments of the United States and Mexico formally created the 'Bracero Program' to allow Mexicans to cross the border legally in search for work wherever labour was needed in the United States. The Bracero Program initiated a heavy and persistent flow of migrants from Mexico and other Latin American countries to the borderlands, and in particular to Tijuana. Northern Mexico gradually emerged as a region of settlement and production, in part as a result of a federal strategy to strengthen the border region's infrastructure. In 1965, the Mexican government introduced the Border Industrialization Program (BIP). Its purpose was to turn the region into a dynamic growth pole and to relieve unemployment in border cities. The government now permitted Mexican and foreign-owned factories to operate along the border duty-free, on condition that they exported all their products. This strategy paved the way for the 'maquiladora industry' which took the form of plants assembling industrial goods, principally for transnational corporations with US-headquarters (Sklair 1993). Throughout the 1970s, 1980s and 1990s, this type of industrial development, embedded in patterns of flexible accumulation and specialization (Harvey 1990), acquired a crucial importance for the entire border region, bringing with it thousands of jobs. 
For local authorities on both sides of the border the social and environmental implications of these developments soon proved daunting: witness problems of housing and urban infrastructure related to the rapid inflow of migrants and industrial plants, problems of public security and safety related to illegal migration, and problems of environment caused by the almost unrestricted maquiladora industry. In particular on the Mexican side, the state and local governments were not sufficiently funded, nor technically trained and organized to provide legally based solutions to both the scale and the nature of these problems, including the growth of illegal drug-trafficking (Herzog 1990:109).

Attempts at co-operating across the border to contain the effects of rapid social change were regularly frustrated by the cultural and social cleavages between the two nations. In the early nineties, however, the North American Free Trade Agreement was negotiated and signed, despite traditions of skepticism and a difficult economic conjuncture on the Mexican side (Milner 1999). The three North American states bound themselves to liberalize economic exchanges in a number of fields, and agreed to follow a certain set of institutional procedures when disagreements over those principles arose (Clement ea. 1999). Thus NAFTA institutionalized a considerable degree of economic integration between the three states, lowering the thresholds for trade and other exchanges among them, and paving the way for fast growing flows of goods, services and ideas across the borders. In the process, it effectively diminished the traditional repertoire of government powers and techniques hitherto enjoyed by the three states.

Specific aspects of the NAFTA construction are intended to weaken the power of the state: state functions that have been taken from the three member states have not been transferred to a supra-national authority. Instead, they have been placed outside the reach of the political system. Breaches of NAFTA regulations are dealt with through litigation, in court-like arbitration panels. In this way, NAFTA can be seen as an attempt at drastically reducing political interference with business: the neoliberal rationality from the early 1990s is enshrined in NAFTA stipulations against public regulation and interference (Bislev 1999; Grinspun and Kreklewich 1999), which in very clear terms state that member states are not allowed to assume new functions or take over new areas - change is only allowed in the other direction, towards less state and more market. The trend is thus set towards a state that is less present in society.

North American states have weakened themselves by writing these market-enhancing clauses into the NAFTA treaty. But even if the sovereignty of the state has been undermined by such restrictions, the very existence of NAFTA nevertheless adds an extra layer and a new rationality to the system(s) of governance in the region. The present situation in the SD-T region is one of added complexity, of multi-level governance (Hooghe 1996), of conflicting goals and overlapping jurisdictions. In this, NAFTA reproduces some of the processes in European integration, where multi-level governance is a much-debated problem. The North American structure, however, is rather different from the European one. In the EU, specific competencies have been transferred to EU institutions as a supra-national authority, and the EU has ambitions also in non-economic areas like the social field, education and the environment. In NAFTA, these issues are handled in side agreements which do not form part of the institutionalization of NAFTA and depend upon further political processes for eventual implementation.

Both the NAFTA and the EU can be understood as instances of globalization - as regional integration schemes interpreting and implementing the trends towards increasing global interconnectedness (Dicken 1988; Tomlinson 1999). They do it in different ways, but both schemes involve considerable changes of the nature of stateness - not least visible in the security domain. The classical Weberian definition of the state as 'a human community that (successfully) claims a monopoly of the legitimate use of physical force within a given territory' (Gerth and Mills (1958): 78 [Weber 1918]) becomes less adequate for understanding a state that must now compete with other organizations of organized force. A state that is also less capable of handling the novel versions of security - environmental and human security - and whose ability to command allegiance and manage identity may therefore suffer (Wallace 1995; Kersbergen 2000). 


\subsection{Changed concepts of security}

Globalization plays an important but ambiguous role for the current understanding and framing of security. If 'functional integration' is an important characteristic of globalization (Dicken 1988), many theories of international conflict would suggest that societies depending on each other for vital functions will not engage in armed conflict (LeBillon and Duffield 2000). And if globalization brings convergence around a democratic capitalist model (Fukuyama 1992), other theories will predict that democracies do not wage war against each other - or rarely do so (Sørensen 1993: 91 ff.; Kegley and Wittkopf 1999: 52 f.). On the other hand, globalization has meant an increasing role for market forces and therefore growing disparities in the wealth of different nations: while bringing prosperity to nations that successfully integrate, it has brought further misery to those that fall behind. In some cases, though not in all, globalization has also implied an increase in domestic inequality. World Bank data show that on an aggregated level, there is no correlation between international integration, measured as trade exposure, and domestic social inequality (Lambright and v.d.Walle 2000). If, however, globalization is operationalized as institutional liberalization of the economy, there is a strong correlation: in Mexico, for example, liberalizing reforms in the 1980s were followed by an increasing Gini co-efficient - from 0.419 in 1984 to 0.519 in 1994 (Stewart and Berry 1999: 171).

Before the welfare state, the term of security was much less used, and talk was about 'defence' (itself a euphemism for 'war'), when threats to the existence of states were discussed. The advent of the welfare state meant that the state became a popular project. A new governmentality took over (Dean 1999), aimed at increasing not the might of the nation, but the welfare of the people. Security remained a national project, and threats, although they could be broadly defined, were threats against the existence of the nation-state. In his treatise on national security, Buzan extended the concept of security but clearly still saw it in terms of physical safety (Buzan, 1991).

Today, security is viewed as a much broader phenomenon. The end of the Cold War brought to a close a number of inter-state conflicts. But it also triggered many new - mostly intra-state conflicts. Where the concept of security previously revolved around the territorial integrity of these states, it has now gradually been extended to encompass intra-state public and human security, including poverty reduction goals. And where the internal security of a state was largely a military matter within each of the two competing blocs, it has now been transformed into an international issue within a complex, multipolar structure of many actors.

At the international level, security is to an increasing extent viewed as closely connected with public welfare and the organization of the security sector as such (Kaldor 2000). Inequalities - both domestic and inter-societal - are viewed as breeding conflict, creating a greater propensity for uncontrolled and armed conflicts (Hurrell 1999). Non-state actors operating at the international level have increasingly appropriated a security role - either as security providers or as specialized fora of professionals whose voices authorize new and particular approaches to security, conflict prevention and conflict management. Principles of effective security sector governance and the role of development co-operation are currently debated in a number of international organizations, including the OECD (e.g. Hendrickson 1999; OECD 2000; Axworthy 1999; Duffield 1999).

In contemporary political science textbooks 'national security' is often reduced to a short discussion of old-fashioned military concepts, while long sections on environmental risk and social problems dominate the security issue (Kegley and Wittkopf 1999). Problems like drugs, the environment, domestic prosperity, competitiveness, social partnerships, free trade, energy provision, democracy, etc., are given prominent treatment in official security documents (White House, 1995; www.whitehouse.gov). One way of conceptualizing this is to employ the 'securitization' term (Wæver 1997): Conceptualizing an issue as 'security'-related justifies and paves the way for extraordinary forms of management, such as keeping things secret, conscripting soldiers, incarcerating citizens, and levying new taxes. In other words, security discourse is a claim for exceptionality from the popular project of the welfare state.

Because of globalization and the reduction of the state, the task of managing security has shifted partially to individuals and to local organizations and agencies, operating in partnership with 
state authorities Also at this level, security may be an exceptionalist discourse. At the local level one can, under the security banner, dispense with good manners, comfort and politeness. Businesses must protect themselves against illegal acts that threaten their profits and existence, and the 'security' discourse allows them to supervise, sometimes intimidate, their customers by the use of armed guards and CCTV cameras.

Furthermore, however, the discourse on social issues has been influenced by the broader notions of security: a new welfare state discourse is emerging, stressing less the social aspects of solidarity and re-distribution, and more the issue of 'securing' welfare against the risks of modern living. The governmental rationalities of 'post-modernism' (Giddens 1990:52) or 'advanced liberalism' (Dean 1999:164 ff.) bring this security issue all the way to the responsibility of the individual: technologies of the self, self-improvement practices in health and social areas, are now part of the repertory of governance ideas.

\section{Life, risks and politics in the San Diego/Tijuana border area: Governance and discourses of insecurity}

In a modern border region, where the risk of armed conflict at the inter-state level has become a remote and abstract memory, the altered nature of security becomes clear. Military forces are certainly present, but as guards against illegal migrants and drug traffickers along the border (Andreas 2000). The substance of security has been almost completely reversed: risk and security issues are omni-present concerns for public and private organizations operating in the region, while the national issue has almost disappeared from the equation.

In the last decade, cross-border legal trade has increased; Mexican exports to the US have grown sixfold, and its imports from the US tripled (Clement ea. 1999:15f.). An equivalent increase, however, has taken place in trafficking in drugs, immigrants and other illegal goods and services. Security problems are perceived as ever more pressing, but the participants in the security discourse make up a new and diverse group. Although NAFTA is not, in the sense of the European Union, really a new level of decision-making above the national one, it does introduce new elements and a new rationality into the complex of public authorities in North America. A region like SD-T now has respectively four (Mexico) and five (the US) levels of decision-making influencing social life: federal, state, county (the US) and municipal/city - plus the supranational aspects. And each level exists in a US and a Mexican version. Each level and each nation add a new context, a new set of rationalities in different compositions.

This section tries to capture specific instances of how the notion of (in) security is being represented, institutionalized and handled locally. In other words, the idea is to suggest how local perceptions of life and risks in the border area can be seen to impact on local attempts at managing the border area. The term 'manage' (rather than 'govern') is crucial, for in line with the account in section one, a good many of the events, crises, scandals and misdeeds that feed the border discourse and form an important part of life at the border are being played out in a de facto political vacuum: quite often the (local) authorities on both sides of the border have neither the power nor the resources to address the catalogue of problems that economic liberalization in the 1990s has only exacerbated.

A fast growing body of organizations, institutions and networks, many locally embedded, are giving voice to particular aspects of the border problematique, a tangible demonstration of the retreat of the public sector and the complexity of post-modern security. At present, our empirical investigations only enable us to sketch the contours of the ways in which these local concerns translate into discursive and social practices that try to make up for the political paralysis. Therefore, far from qualifying the discussion we have launched in this paper in any substantial way, the observations below serve to map out the orientation of future empirical work. 


\subsection{The federal and state levels}

Diving into the plethora of fora currently striving to give voice to the border issues, it is instructive to see how the US federal government views the situation and what initiatives, if any, it proposes in order to manage the Southwest border (which is of course much more than the San Diego/Tijuana region) above and beyond what is prescribed by NAFTA. And the post NAFTA period has in fact produced a number of responses that speak the (in)security issue and the dark side of economic integration. In May 1999, president Bill Clinton launched his Interagency Task Force on the Economic Development of the Southwest Border. This and other efforts such as the Southwest Border Partnership from 1997, were created to address "the numerous problems that plague the southwest Border Region". The latter construction amounted to a reorganization of the so-called Empowerment Zones, Enterprise Communities and Champion Communities, all federal initiatives designed to

"provide economically urban and rural areas and communities with real opportunities for growth and revitalization. [Their] mission is to foster self-sustaining, long-term economic development in areas suffering from pervasive poverty, unemployment, and general distress and to demonstrate how communties can achieve self-sufficiency by following innovative and comprehensive strategic plans formulated and implemented by alliances among public, private and nonprofit entities." (www.treas.gov/sw_border/origins).

In particular in the presentation of the Task Force, it is stressed that it highlights the President's formal recognition of "the challenges confronted by many Border communities on a daily basis". I.e there is evidence of the federal level recognizing the low politics of economic integration at the Border. At the time of writing, it is however not entirely clear just how much financial and other muscle that backs the initiative. Its mission is basically described as one of coordinating and better leveraging "existing Administration efforts aimed at the Southwest, in concert with locally led efforts, in order to elevate the standard of living and overall economic profile of the Southwest Border Region". Interestingly for our purpose, its framework includes identification and development of "new options that fill any current 'gaps' in federal government efforts". The goals are listed under four headings, Community Planning and Investment; Development of Human Capital; Sustainable Development and Infrastructure; and International Cooperation and Law Enforcement. The latter specifies two spheres of action: "Protecting the Border, shoring up law enforcement and preventing crime"; and "Advancing our partnership with Mexico". In terms of the thematic organization of the web-site description of the Task Force, the order of appearance sketched foregrounds 'soft law' techniques and amounts to a very noticeable backgrounding of themes like crime and traditional law enforcement.

This is in stark contrast to comments by observers critical of the Federal Government's handling of the Border Region. When talking about the Southwest Border, crime is almost always synonymous with drugs and/or illegal immigration into the US. In his scathing critique of the U.S. and Mexico post-NAFTA drug control record, Peter Andreas sums up the situation on the U.S.Mexican Border as a result of two incompatible efforts: on the one hand, the creation of a borderless economy and, on the other hand, an increasingly, it appears, barricaded border (Andreas 2000; www.zianet.com/ircl/bordline/2000/b166comp). The lion's share of money and political attention dedicated to managing the border, in the early-mid 1990s mainly with a view to securing the passage of the NAFTA, has been channelled into escalating efforts to police drug flows and, not least, projecting an image of drug control progress. A whole string of "highly visible but misleading indicators of government resolve - increased arrests, seizures, and so on - helped sustain this image and obscured the failings and flaws of the enforcement effort" (Andreas 2000).

Post-NAFTA, however, this policy response has generated a whole new set of increasingly intractable problems in the Border Region, a development which has been further spurred by the relative success of the U.S. interdiction campaign in the Caribbean which has made Mexico the 
more attractive launch pad for cocaine into the U.S. A particularly vicious circle whereby improvements in cross-border management methods are promptly matched by improvements in the methods of drug smuggling, which are then accompanied by heightened media awareness, which in turn increases public pressure on government to do something, can be identified. And, unlike what the thematic organization in the President's Task Force suggests, relatively few resources are spent on demand-focused measures (i.e. curbing the American appetite for illegal drugs, notably by education and prevention).

The insistence of maintaining the (practically impossible) distinction between on the one hand wanted migrant labour and, on the other hand, the unwanted persons in whom this labour is embodied makes it difficult to address many of the social and economic problems that plague (to use the phrase used in the Task Force quoted above) the Border Region. What the Task Force calls "new options that fill any current 'gaps' in federal government" don't come easily when the language available for speaking an important aspect of the border problematique is limited to a vocabulary tied to notions of illegal aliens. And, "rhetoric aside [...], the de facto immigration policy of the US government is not to make the US-Mexican border impermeable to the passage of 'illegal' entrants, but rather to regulate their 'flow', while at the same time maintaining the official distinctions between the 'sending' and 'receiving' nations, i.e. between kinds of peoples, that is, to constitute classes of peoples - classes in both the categorical and social sense" (Kearney 1998: 124).

All the bravado and all the fancy interdiction technology serve mainly to pacify an American public increasingly intent on defending its identity as North Americans, while the undisturbed flow of illegal aliens continues to provide the South West Border and beyond with a low cost labour force: "Having lost control of geographic space in the Border Areas " (Kearney 1998: 126), European-Americans view their power to legislate identities and practices as 'illegal' as their last, if fast crumbling, identity bastion.

South of the border, Mexican federal authorities have been highly critical of the USgovernment's treatment of the question of immigration. The Mexican government considers it damaging for the relationship between the two countries that US authorities deal with the issue as a justice and police - law and order - problem. On the Mexican side of the border, the issue of immigration appears as a problem of development - the income gap between the two countries is seen as the root cause. But its own development policies have caught the Mexican government in a trap. The maquiladora industrialization model was conceived in order to raise the economic level of the area, but it is a strategy that entails a level of wages so low that it will continue to stimulate Northwards migration. Furthermore, the strategy creates unintended consequences in other areas and for other layers of government, in particular with respect to urban governance at the state and municipal levels (housing, public service and security).

At the state level - in this case the state of Baja California - authorities are very well aware of these contradictions and their effects on urban governance. In a 1996 program concerned with urban development in the region, Baja California state authorities established that the state has become "urban" - $80 \%$ of the state's rapidly increasing population (a consequence of the flow of people into the region) reside in areas which are characterized as urban, localized in the North near the border. More than half of the state's population lives in the City of Tijuana. The central and southern parts of the state are mostly rural, housing the rest of the population. The consequences are the following:

"The accelerating and disordered demographic growth in urban areas has generated a high demand for work and services, as well as maladjustments that become expressed in social conflicts..." (http:/www.baja.gob.mx/biblioteca/plan.

In another section of the program, this diagnosis is invoked to formulate a number of goals and concrete strategies with regard to future urban policies: the establishment of better urban planning systems, a higher degree of land tenure security and an improvement in public participation in urban policies. 
In a program concerned with social welfare, the state authorities of Baja California again refer to the rapid increase in the population, seeing it as a consequence of the flow of migrants from other parts of Mexico. Interestingly, the state government then directs its attention to the federal level:

"It is important to implement policies at the national level which can serve not only to redirect or resettle possible migrants in their sites of origin, or in other poles of development...but which can channel special resources to the state as it is a receiver of migrant populations." (op.cit.+/poblacio.htm:2).

Here, it is argued that the flow of migrants should be redirected from their place of origin to other places than Baja California, and that the state of Baja California should receive special help due to its status as a receiver of migrants. On the other hand, the body mostly responsible for the delivery of this help is the federal government that resides in the capital of the country.

Given Baja California's proximity to the United States, problems such as the northbound trade in drugs and immigrants, and the southward flow of different types of contraband have produced a level of violence not found in many other regions of Mexico. For one thing, violence and insecurity in this region often stem from confrontations between different economic groups competing for some degree of control over the area's illegal activities. Furthermore, this seems to take place with the consent and sometimes even the protection of various law enforcement agencies, in particular police groups. A final important aspect has been the increasing militarization of the region - a consequence of the 'war on drugs'. One of the most negative results of this development is the violation of basic human rights. As pointed out in a recent study by the Center for Borderstudies and Promotion of Human Rights (Mexican):

"In states with large indigenous populations (such as Chiapas), complaints of human rights violations usually cite the Mexican military and paramilitary groups who attack civilians suspected of being members of or sympathizers with guerrilla groups. On Mexico's northern border, however, added to the list are agents of the Federal Judicial Police (frequently members of the military "on leave"), officers of various State Judicial Police (PJE) units, and municipal policemen, who, taken together, represent the region's primary perpetrators of human rights violations. Torture, abduction, forced disappearance, robbery, extortion, assault, illegal entry, and murder have become common components of the workaday tasks of such law enforcement agents." (Solís 1998:1).

Federal and state authorities have taken several steps to improve the situation. In the early 1990s a special, 'clean and honest' police force was established - the Beta Group - composed by well-estimated, -salaried and -trained officers. Recent evidence suggests, however, that corruption has become pervasive within the forces, much to the regret of public and private authorities in the region .

\subsection{The local level}

With these glimpses of federal and state government's discursive and social intervention in the Southwest Border Region- and the underlying rationalities of this intervention - we will turn our attention to actors and institutions in the San Diego/Tijuana Region. In the City of San Diego, conversations with different parts of the administration about cross-border issues reveal a history of slow rapprochement, relatively few and feeble institutionalized instances of hands-on collaboration, though possibly growing awareness in the political sphere of the need to do something proactively rather then merely fending off Border-related crime and being seen to seal off the Border from the 
'Other' ${ }^{1}$. However, if what a lot of local residents instinctively want to do is to forget about everything south of the border, then addressing Border issues in a more profound way and embarking upon serious cross-border co-operation become less of a political priority and are currently curiously absent from the both the City's and the County's official political communications.

One example of the relative silence that surrounds the Border question is the 2000 State of the County Address, which only mentions it twice, both times encoded in a economic, NAFTA like mode. The first reference does speak the insecurity theme, though very indirectly:

"I would like to take a few moments to acknowledge some of the Board members" specific accomplishments in the past year. Supervisor Greg Cos initiated the Border Development Zone - SB207 - to provide badly-needed funding for border infrastructure, so $w$ can take full advantage of the opportunities created by expanding free trade with Mexico" (Jacob, 2000, www.co.sandiego.ca.us/cnty/bos/sup2/speeches/2000sca: p. 2).

And towards the end of the address, in a section on what the county has done and can do to stimulate the local economy:

"To further the enormous potential of cross-border trade, I will work to expand the model created by the East County Economic Development council with the Connectory to include Mexican companies in our data base, strengthening our economic ties and creating opportunities for businesses on both sides of the border" (ibid, p. 8).

In similar vein, among the themes discussed in the mayoral contest in San Diego in 2000, the border co-operation issue has been left largely unaddressed. None of the contestants have chosen to stress an aspect of local politics which may be too controversial to get out the vote among the San Diego citizens most likely to vote.

By contrast, at the administrative level, many local government officers appear acutely aware of the need to consult and work with their counterparts in Tijuana much more systematically and strategically. In the early 1990s co-operation between the two cities was close to non-existent. Following the intensification of activities in the wake of NAFTA, it was realized, on both sides of the Border, that NAFTA did not have sufficient teeth in relation to a host of practical and very real issues in the San Diego/Tijuana Region. San Diego's then Mayor Golding initiated a decision to set up a framework for co-operation between the two cities capable of addressing these issues and today many San Diego City departments are involved: initially five and now ten committees have been set up (economic development, transfer of technology, environment/recycling, public safety, libraries, culture, border crossing, transport, water, sewage, telecomm., planning and land use). Every committee has a double chairmanship - the two department directors - and they meet every month with a general commission meeting every three months presided over by the two mayors.

However, despite recent years' trend towards more local government level cross-border cooperation, officers also point to obstacles in the two political systems that continue to thwart collaborative efforts, long-term commitment and planning. Therefore the committee framework described in the above is less of an executive body and more of a discursive community, voicing concerns and problems that other bodies then pick up and, perhaps, translate into action. On the one hand, after 11 years with PANista government, the City of Tijuana has experienced modernization and restructuring initiatives, trends also known across the Border in San Diego; and the issue of fraud has been addressed in a much more concerted fashion than before. On the other hand, the high turnover of both councillors and officers (re-election impossible combined with politically appointed key administrative staff) creates discontinuity. On the U.S. side, formal government

\footnotetext{
${ }^{1}$ The following observations/reflections are based on interviews with officers in the City of San Diego and County of San Diego in March 1999 and 2000.
} 
intervention, both local and even more so if cross-border, which involves strategic planning, funding and investment is seriously hindered by the general U.S. government phobia and intuitive hostility to anything that smacks of centralization. Instead, what tends to happen in these semiformalized cross-border government set-ups (remember, they are not backed by a formal legal basis), is that ideas are presented and quite often rejected, but not necessarily killed. What then sometimes happens is that they gain a life of their own, get latched on to a non-governmental organization's project and then take off. Networks and linkages and a lot of informal interaction with the world outside the committee system are fundamental for the process to move on. Any realization of the idea that a border region contains a permanent transfer of ideas seems to depend on these ideas being lifted out of formal government structures and mediated and negotiated by other forces and interests.

Thus, despite the good intentions of the two administrations, several positive experiences at the interpersonal level across the two administrations, and the very tangible and material common concerns that they share, the general public remain hesitant, if not downright reluctant to entertain ideas about closer collaboration. The framework for action for politicians remains severely restricted by the negative connotations that life and social memories along the Border keep generating/feeding. People in San Diego remain unenthusiastic about Tijuana, which is seen as dirty, dangerous, and in every sense disheartening; wealthy people certainly do not cross the Border out of pleasure; Mexico/Tijuana is not only another country, it is another world, poor and corrupt, with a totally different system. The San Diego Business community is awash with anecdotes about how impossibly slow/unstructured/irrational Mexican business people are. In Tijuana, Los Angeles stands out as the more obvious object of economic and cultural interaction.

This is the background against which we see the emergence of a whole raft of sometimes competing, sometimes overlapping, sometimes supplementary, sometimes co-ordinating fora, to various degrees empowered and/or intent on promoting specific policies and initiatives. SANDAG's list of binational links (www.sandag.cog.ca.us/projects/binational/binational links) ${ }^{2}$, many of which represent responses to the local concern with (in) security gives an idea of the multifarious interests at play

SANDAG (San Diego Association of Governments) is part of the region's formal governance structure, albeit not directly accountable to the citizens in the region. And this structure is vast and many-facetted, as the links list demonstrates. Created in 1966, then as the comprehensive Planning Organization within the County administration under a state authorized Joint Powers Agreement, it was renamed SANDAG in 1980. From its modest beginnings in the late 1960s, it gradually increased its powers, in particular in the areas of growth management, habitat conservation planning, open space, traffic management and criminal justice, and its membership in the 1980s and 1990s. Today, the region's 18 cities and county government are voting members of the association. Supplementing these voting members are a number of advisory representatives, including the federal government and Tijuana/Baja California, Mexico. A forum for regional decision-making, SANDAG aims at building consensus, planning strategically, obtaining and allocating resources, and providing information on a broad range of topics relevant to the region's quality of life, many of which are of course intricately related to the region's specific socio-economic traits. In its own

\footnotetext{
${ }^{2}$ The organizations on SANDAG's list have been categorized as either academic (e.g. California Center for border and Regional Economic Studies; Institute for Regional Studies of the Californias; Northern Border College; San Diego Dialogue; UCSD Center for US-Mexican Studies); economic (NAFTA; North American Development Bank (NADBank); IMF; OECD; UN Economic Commission for Latin America; Inter-American Development Bank; World Bansk; International Development and Research Centre; SECOFI-NAFTA; Secretariat of Finance and Public Credit); environmental (Environmental Protection Agency (EPA); Commission of Environmental cooperation (CEC); Border Environmental Cooperation Commisssion; International Boundary and Water Commission; Secretariat for the Environment, Natural Resources, and Fisheries; National Commission for Knowledge and Use of Biodiversity; Center for Energy Studies; Border Pact (Partners in Action); Border Eco Web); Geographic Information Systems (Transboundary Resource Inventory Systems); governmental (Baja California State Government; Embassy of Mexico in the United States; National Institute for Statistics, Geography, and Information; Mexican Transport Institute; Organization of American States; SECOFI-NAFTA; Secretary of Exterior Relations).
} 
words, it does so "without the need to create costly new government". Governance-wise, SANDAG illustrates the degree of multilevelness in the region. It is, however, beyond the scope of this article to provide a more precise idea of SANDAG's (and other actors' mentioned here) place on the continuum of stateness and the correlation between this place, the powers and responsibilities assigned, and the nature of statehood. This is of central concern to the study that the present deliberations are planned to prepare.

At this point, we will limit our investigation of SANDAG to a conference sponsored by its Committee on Binational Regional Opportunities and the Consul General of Mexico in San Diego which both reflects and rearticulates the insecurity and the multi-level governance themes. Interestingly, its take on the situation is to view it as the result of deficient communications rather than deficient institutions - so there is a sense in which it depoliticizes the problems at hand and reduces them to differences in communication modes.

"Building a Strong Region through effective communication, Seizing Opportunities in the California/Baja California Region. July 2000 conference sponsored by SANDAG's Committee on Binational Regional Opportunities and the Consul General of Mexico in San Diego on the opportunities and challenges of cross-border communication:

Over 4 million people live in the San Diego-Tijuana region, and projections indicate that within the next 15 years, our binational population could grow with another 2 million people. This rapid development has spawned a myriad of environmental, social and political issues unique to the border region. As a result, the number of organizations and agencies conducting work along the border has markedly increased in recent years, as has the level of cross border communication and collaboration between and among the various sectors of our society. However, those involved in cross-border communication activities often encounter difficulties working across an international boundary. The ability to communicate across the border with the community and with the media is of utmost importance in order to promote existing and new cross-border initiatives.

Additionally, a great deal of attention has been given to the problems that arise along our shared border resulting in a distorted public perception of the border region. Yet, many successful cross-border initiatives demonstrate that collaboration and regional Co-operation can and do work" (www.sandag.cog.ca.us/projec").

Blaming the difficulties of cooperating across the border on 'distorted public perception' due to excessive attention to border problems seems to be a particularly impotent approach to the many problems in the area, an approach more intent on improving images than addressing problems.

South of the border, security problems may be more concrete and more acutely experienced. Recognized by the public and the municipal authorities of Tijuana as one of the highest prioritized fields of intervention, the security sector became reorganized and reinforced in the 1990s. A special municipal division for public security was established during the 1995-98 administration - la Secretaría de Seguridad Pública Municipal (PMD 1996). Among its specific objectives are:

"To stimulate the participation of the different sectors of the community in the Municipal security programs...

"To reinforce the relations, in terms of security, between the Municipality, other public institutions, and private entities, at the local, national and international levels.." (PMD 1996)

In the 1998-2001 municipal development plan (PMD 1998:113, 117), further steps to include citizens and 'private entities' in the management of security were taken. According to this programme, one of the most important technologies of crime prevention is "the consulting with and 
participation of citizens in municipal security issues". The plan furthermore emphasizes the importance of "Establish[ing] an agreement with the Association of Private Security Companies", with a particular eye to colaborating with those firms in order to "Establish networks of vigilance, supervison, logistic support and training”.

\subsection{Non-Governmental Organizations}

On both sides of the border, NGOs of a variety of types have increased their presence in the regional arena over the last couple of decades. On the Mexican side of the border, this increase has been related to the process of political democratization and decentralization since the 1980s. Of particular interest in the present context, however, is the gradual development of transborder fora such as the San Diego Dialogue. San Diego Dialogue was established in 1991 and is a self-funded, regional public policy centre based at the University of California, San Diego. Directed by an invited membership of approximately 150 civic and community leaders from San Diego and northern Baja California it sponsors research projects and public education programmes on issues affecting the future of both San Diego and the San Diego/Tijuana cross-border region. Its research agenda and public programmes aim at addressing

"the challenges and opportunities for regional development, including:

- $\quad$ Planning a common, sustainable urban future with Tijuana;

- $\quad$ Enhancing the role that both San Diego and Baja California can play in the growing global economy;

- $\quad$ Ensuring educational achievement for all students in our elementary and secondary schools;

- Creating an effective structure for regional governance." (www.sddialogue.org/home/page)

These four issues are not markedly different from the Federal US governments themes for its Task Force mandate. But the San Diego Dialogue offers a fairly critical perspective on the Border region, and is definitely concerned with politics in its discussion of both the roots of the region's problems, future scenarios and specific solutions: Ethnicity and immigration are not reduced to a matter of communication, on the contrary, "engaging ethnic and immigrant communities in global trade ... is one of the most important challenges for our region as it embraces the global economy". And the notion of security is related to the creation of a more equitable society. However, as indicated in the above quotes, official comments on the state of the region and its future all presuppose embracement of the global economy and the inevitability of more growth. With Giddens, the Dialogue asks "How far can we (...) harness the juggernaut, or at least direct it in such a way as to minimize the dangers and maximize the opportunities which modernity offers to us?" (Giddens 1990: 151). Obviously, a majority of residents have no faith in anybody's ability to steer the juggernaut.

Together with the Public Policy Institute of California SDD has just released the results of a survey of San Diego residents and their attitudes towards the region's quality of life, which shows that only $18 \%$ of area residents think their county will be a better place to live in 10 years from now. There are many and interrelated reasons for this gloom - perhaps the main concern is the perceived implications of a rapidly growing population and the pressure this generates on the region's social and physical infrastructure, on its economic and cultural resources, and thereby on the security situation, in the broadest sense of this term.

\section{Concluding remarks}


The above considerations seem to indicate that security problems in the SD-T area are problems of growth: growth in the number of residents in the area, stretching all infrastructural and institutional capacities and resources to breaking point. And growth in cross-border traffic and trafficking, trailing a long line of typical border area problems of smuggling and legal evasion. Together, these growth phenomena create a complex and fluid situation, where numerous actors and structures interweave and relations are constantly shifting. Establishing any sense of security in such a context is extremely difficult.

On the supra-national level only economic regulations have been established - NAFTA does not concern itself with neither national security nor the social and human effects of freer trade.

At the federal levels, the US Federal Government has approached the situation with its Task Force signalling preventive efforts and soft law regulation, but the strategy pursued in practice has been one of militarization. The very visible effects of militarization - patrols, arrests, convictions, raids - are well suited for demonstrating performance, and as such fit in well with the government's image strategies and with management ideas that prioritize the monitoring of performance. Until now, however, they have not proven successful in combating any of the security problems - real or imagined - in the region.

The Mexican federal government has plans for developing the area in an economic sense, by permitting maquiladora industries and releasing the traditional strong state controls. Security problems are also here handled by militarization, although the task is made difficult by corruption and inadequate equipment and provision of the forces deployed. The Mexican government seems to be caught in a trap where its continued reliance on the export oriented industrial development will produce severe problems in terms of safety and security in the northern border region. At the same time, state authorities blame federal government for its lack of interest in the social consequences of the development strategy.

At the level of local authorities, city and county, US politicians appear wary to be seen to get too involved in problems whose cure runs counter to deep-seated notions of minimal government: Regulating economic and residential growth means limiting the freedoms of citizens, and that is not popular among the voters in the region. A number of county and city officials on the San Diego side, however, show great enthusiasm for working with their Mexican counterparts. They experience the direct difficulties of solving any sort of societal problems in a globalizing region if they do not co-operate with neighbouring authorities and institutions.

The Tijuana local government looks very much to the US as a source of resources and solutions to their problems. Interestingly, however, it seems that Tijuana authorities quite explicitly have opted for a 'partnership' strategy in terms of the organization of the security. In this line of thinking, security has become an issue that should involve society, and in particular the private sector provision of security.

The non-state actors in the region have an important and increasing role in pointing out the real threats to the security and well being of citizens and dysfunctions of the policies pursued. The more precise form and extent to which NGOs, research institutions, other associations, and not least private businesses, are involved in the co-ordination of the multiple interventions necessary to counter those threats, deserve a much more detailed study than we have been able to carry out in the present paper. At any rate, we may expect that 'security problems', even when defined as existing locally and in non-military matters, are hard to solve in the absence of an active and responsible state.

\section{References}

Amin, A. (1997): "Placing Globalization”, Theory, Culture and Society, vol. 14(2), pp.123-37.

Andreas, P. (2000): "US-Mexico Drug Control in the Age of Free Trade", borderlines, 66, vol. 8 no. 4, April (on www.zianet.com) 
Appadurai, A. (1996): Modernity at Large. Cultural Dimensions of Globalization, Minneapolis: University of Minnesota Press.

Axworthy, L (1999): Human Security: Safety for People in a Changing World, Department of Foreign Affairs and International Trade, Canada.

Bislev, S. (1999): “Introduction”, pp. 1-14 in Appendini, K. \& S. Bislev (eds.), Economic Integration in NAFTA and the $E U$, London: Macmillan

Buzan, B. (1991), People, States and Fear, Brighton: Harvester

Clement, N. e.a., (1999): North American Economic Integration, Cheltenham: Edward Elgar

Dean, M. (1999): Governmentality. Power and Rule in Modern Society. London: Sage

Dicken, P. (1988): Global Shift. London: Chapman

Duffield, M. (1999): “Globalization and War Economies: Promoting Order or the Return of History?", Fletcher Forum of World Affairs, vol. 23(2), pp. 19-36.

Fukuyama, F. (1992): The End of History and the Last Man, N.Y.: Free Press

Gerth, H.H. \& C.W. Mills, 1958 (1946): From Max Weber, N.Y.: Oxford University Press

Giddens, A. (1990): The Consequences of Modernity, Cambridge: Polity

Grinspun, R., \& R. Kreklewitch (1999): “Institutions, Power Relations and Unequal Integration in the Americas: NAFTA as Deficient Institutionality", pp. 17-33 in Appendini, K. \& S. Bislev (eds.), Economic Integration in NAFTA and the EU, London: Macmillan

Harvey, D. (1990): The Condition of Postmodernity. Massachusetts: Blackwell Publishers Ltd.

Hendrickson, D. (1999): A Review of Security-Sector Reform, Working Paper, The Conflict, Security and Development Group at the Centre for Defence Studies, Kings College, University of London.

Herzog, L. (1990): Where North Meets South: Cities, Space and politics on the U.S.-Mexico Border, Austin: center for Mexican American studies, University of Texas at Austin.

Hooghe, L. (1996): Cohesion Policy and European Integration - building multi-level governance. Oxford: Oxford University Press

Hurrell, A. (1999): "Security and Inequality", pp. 248-71 in Hurrell, A. \& Woods, N., (eds.), Inequality, Globalization and World Politics, Oxford: Oxford University Press

Kaldor, M. (ed)(2000): Global Insecurity. Restructuring the Global Military Sector. London: Pinter.

Kearney, M. (1998): “Transnationalism in California and Mexico at the End of Empire”, pp. 117-141 in Wilson, T. M. and Donnan, H. (eds): Border identities. Nation and state at international frontiers. Cambridge: Cambridge University Press

Kegley, C.W. and Wittkopf, E. (1999): World Politics: Trend and Transformation. N.Y.: St. Martin’s Press

Lambright, G. \& N. v,.d. Walle (2000), “Globalization in the Developing World: State Capacity, Social Fragmentation, and Embeddedness", pp. 123-152 in Aulakh, P.SA. \& M.G. Schechter (eds.) Rethinking Globalization(s) . London: Macmillan

Kersbergen, K.v. (2000), "Political Allegiance and European Integration", pp. 1-17 in European Journal of Political Research, 37

Le Billon, P. and Duffield, M. (2000): "Globalisation, Governance, and Conflict: Vulnerability and the Political Economy of Contemporary Wars". Paper for 29th International Geographical Congress, 14-18 August 2000, Seoul

Lynn Doty, R. (1996): The Double Writing of Statecraft. Exploring State Responses to Illegal Immigration, Alternatives vol 21, pp.171-89. 
Miller, P. and Rose, N. (1990): ‘Governing Economic Life’, pp. 1-31, Economy and Society vol. 19.

Milner, H. (1999) "Regional economic co-operation, global markets and domestic politics: a comparison of NAFTA and the Maastricht treaty“, pp. 19-41 in Coleman, W.D: \& G.R.D. Underhill, eds. Regionalism and Global Economic Integration, London: Routledge

OECD (2000): Security-Sector Reform and Development Co-operation: A Conceptual Framework for Enhancing Policy Coherence, Informal DAC Taskforce on Conflict, Peace and Development Co-operation, Development Cooperation Directorate. Paris: OECD.

Pierre, J. (2000): Debating Governance. Authority, steering and Democracy. New York: Oxford University Press

PMD (1996): Plan Municipal de Desarrollo 1996-1998, Tijuana: Copladem -15 Ayuntamiento de Tijuana

PMD (1998). Plan Municipal de Desarrollo 1998-2001, Tijuana: Copladem -16 Ayuntamiento de Tijuana

Rosenau, J.R (2000): “Change, Complexity and Governance in Globalizing Space”, pp. 167-200 in Pierre, J. (2000): Debating Governance. Authority, steering and Democracy. New York: Oxford University Press.

Salskov-Iversen, D., Hansen, H.K and Bislev, S. (2000): "Governmentality, Globalization and Local Practice: Transformation of a hegemonic discourse", Alternatives. Journal of Social Transformation and Human Governance vol. 25(2), pp. 183-222.

Sklair, L (1993): Assembling for Development: The Maquila Industry in Mexico and the United States. Rev. ed. U.S.Mexico Contemporary Persepctives Series, no. 5. La Jolla: Center for U.S.- Mexican Studies, University of California, San Diego.

Stewart, F. and Berry, A. (1999): “Globalization, Liberalization and Inequality”, pp. 150-186 in Hurrell, A. and Woods, N., (eds.), Inequality, Globalization and World Politics, Oxford: Oxford University Press

Sørensen, G. (1993): Democracy and Democratization, Boulder: Westview

Tomlinson, J. (1999): Globalization and Culture. Cambridge: Polity

The White House, February 1995, A National Security Strategy of Engagement and Enlargement, Washington D.C.

Wallace, W. (1995): "Rescue or Retreat? The Nation State in Western Europe 1945-93", pp. 52-76 in Dunn, J. (ed.), Crisis of the Nation-State?, Oxford: Blackwell

Wæver, O. (1997): Concepts of Security, Copenhagen: Institute of Political Science, Copenhagen University 